\title{
Hospitalization due to exacerbation of COPD: "Real-life" outcomes
}

\author{
Lilia Azzi Collet da Rocha Camargo ${ }^{*}$, Maria Vera Oliveira Castellano² ${ }^{2}$ Fábio Checchia Ferreira ${ }^{3}$, Flávio Vieira de Faria ${ }^{3}$, \\ Nelson Carvas JR. ${ }^{4}$

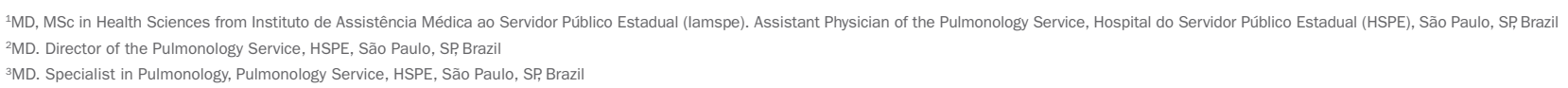

Study conducted at the Serviço de Pneumologia do Hospital do Servidor Público Estadual (HSPE) São Paulo, SP, Brazil

Article received: $10 / 30 / 2016$ Accepted for publication: $11 / 20 / 2016$

*Correspondence: Address: Rua Pedro de Toledo, 1.800 $10^{\circ}$ andar, ala central São Paulo, SP - Brazil Postal code: $04029-000$ liliacolcam@gmail.com

http://dx.doi.org/10.1590/1806-9282.63.06.543

\section{SUMMARY}

Introduction: Hospitalization due to chronic obstructive pulmonary disease exacerbation (eCOPD) may indicate worse prognosis. It is important to know the profile of hospitalized patients and their outcome of hospitalization to customize and optimize treatment.

Method: Evaluation of patients hospitalized for eCOPD, with $\geq 10$ pack/years and $\geq 1$ previous spirometry with airway obstruction over the course of one year at the pulmonology service of a general hospital, applying: COPD assessment test (CAT); mMRc and Visual Analogue Scale (VAS) for dyspnea; hospitalized anxiety and depression questionnaire (HAD); Divo's comorbidities and Cote index; spirometry; and laboratory tests including number of eosinophils, C-reactive protein (CRP), brain natriuretic protein (BNP). Patient progression, number of days of hospitalization and hospitalization outcomes were observed.

Results: There were 75 (12\%) hospitalizations for eCOPD, with 27 readmissions, nine of which during a period $\leq 30$ days after hospital discharge. The main outcomes were: number of days of hospitalization (17 \pm 16.5 [2-75]); hospital discharge (30 [62.5\%] patients); discharge/rehospitalization (18 [37.5\%] patients), eight of them more than once; death (7 [14.5\%] patients), five during rehospitalization. We analyzed 48 patients in their first hospitalization. The sample comprised a heterogeneous group separated in three clusters according to age, $\mathrm{FEV}_{1}$, body mass index (BMI) and CAT. The clusters did not correlate with the main outcomes.

Conclusion: Hospitalization for eCOPD is frequent. The number of readmissions was high and associated with death as an outcome. Patients hospitalized for eCOPD were a heterogeneous group separated in three clusters with different degrees of disease severity and no correlation with hospitalization outcomes.

Keywords: hospitalization for exacerbation of COPD, COPD exacerbation, COPD assessment test, Visual Analogue Scale, COPD death.

Cases of eCOPD accounted for $5.8 \%$ of all respiratory hospitalizations from 1995 to 2000 in Brazil, and $12 \%$ of the patients admitted for eCOPD died. ${ }^{4}$ Between 2000 and 2010, eCOPD was the fifth largest cause of hospitalization through the Brazilian Unified Health System of patients over 40 years of age, with approximately 200,000 admissions and annual expenditure of approximately 72 million reais. ${ }^{5}$

Comorbidities in patients with COPD are important in relation to the outcomes of COPD exacerbations. ${ }^{6} \mathrm{Ag}$ ing is characterized by a mild chronic inflammatory status responsible for the development of comorbidities. 
More than half of patients over 65 years old have more than three comorbidities, and one-fifth have more than five. ${ }^{7}$ There is also the development of mood disorders such as anxiety and depression. Both increase physical disability, morbidity and consumption of medical resources ${ }^{8}$ and can be easily assessed using the Hospital Anxiety and Depression (HAD) Scale validated in Brazil. ${ }^{9}$

Patients with COPD must be evaluated with objective and validated instruments, such as the mMRC scale and the Visual Analogue Scale (VAS) for breathlessness. ${ }^{10}$ The COPD Assessment Test (CAT) is multidimensional; it includes items such as respiratory symptoms, dyspnea, daily life activity, sleep and general condition, measuring the impact of the disease on the patient's life both in periods of stability and exacerbation. ${ }^{11-13}$

The objective of our study was to evaluate hospitalizations for eCOPD, the profile of patients hospitalized for this condition (demographics, CAT, mMRC, VAS, HAD), duration of hospitalization, and outcomes of the hospitalizations in the pulmonology ward of a general hospital.

\section{Method}

We included consecutive patients hospitalized in the pulmonology ward of Hospital do Servidor Público Estadual de São Paulo (HSPE) between May/2013 and May/2014, referred from the Emergency Room, the pulmonology outpatient clinic or transferred from another service, with a diagnosis of eCOPD and at least one spirometry result prior to hospitalization showing airflow obstruction characterized by forced expiratory volume in one second over forced vital capacity $\left(\mathrm{FEV}_{1} / \mathrm{FVC}\right)$ ratio lower than the lowest limit of normality, smoking load $\geq 10$ years/pack and capable to respond to mMRC, VAS, CAT e HAD.

The data used in the analysis of the patients were only related to the first hospitalization for eCOPD in the study period. Data from readmission due to eCOPD of patients already included in the study were not considered for analysis except in cases of death.

Assessment at admission to our ward consisted of standardized anamnesis, revision of medical records, application of the mMRC, VAS, CAT and HAD scales, laboratory tests (leukometry and differential leukogram, C-reactive protein $[\mathrm{CRP}]$ and brain natriuretic peptide [BNP]), and radiological examinations. Clinical analyses of leukometry and differential leukogram were performed using an Advia 2120i Siemens device, whose results are reviewed within preestablished cut-off parameters: there is revision in the case of leukocytes above 13,000 and eosinophilia above $15 \%$. Plasma CRP is measured using immunoturbidimetric assay (Beckman Coulter AU 680 and/or 5,800 analyzers) with cut-off point at $0.5 \mathrm{mg} / \mathrm{dL}$. BNP is measured using a chemiluminescence method on a Siemens Centaur device with a cut-off point of 100 picograms (pg)/mL.

Patients received standard treatment for COPD exacerbation. ${ }^{14,15}$ Antibiotics were prescribed after evaluation of symptoms, leukometry, CRP, and radiological and tomographic findings.

\section{Comorbidities}

After listing the comorbidities, we separated the relevant ones according to the study by Divo et al., ${ }^{6}$ in which 12 comorbidities showed independent risk of death:

- Oncological: Lung, pancreatic and esophageal cancer and, for women, breast cancer.

- Pulmonary fibrosis.

- Cardiac: Atrial fibrillation/flutter, congestive heart failure, coronary artery disease.

- Gastrointestinal: Duodenal/gastric ulcer, hepatic cirrhosis.

- Endocrine: Diabetic neuropathy.

- Psychiatric: Anxiety.

Then, we graded the comorbidities according to the Cote index (value $\geq 4$ indicates a high probability of death):

- Breast (female), pancreatic, esophageal or lung cancer: 6 points.

- Anxiety among women: 6 points.

- Other cancers, hepatic cirrhosis, atrial fibrillation/ flutter, diabetes with neuropathy, and pulmonary fibrosis: 2 points.

- Congestive heart failure, gastric/duodenal ulcer, coronary artery disease: 1 point.

The study protocol was approved by the HSPE Research Ethics Committee under No. 608,487. All participating patients read and signed the informed consent form.

\section{Statistical analysis}

Descriptive analysis of the data on hospitalization frequency, anthropometric and spirometric data, number of exacerbations in the previous year, use of $\mathrm{O}_{2}$ at home, presence of anxiety and/or depression, mMRC, VAS and CAT results, as well as CRP, leukometry and differential leukogram ${ }^{16,17}$ were presented as mean \pm standard deviation, minimum-maximum, or number (percentage), n(\%). Age, CAT, body mass index (BMI) and $\mathrm{FEV}_{1}$ (pre-bd) were standardized to be grouped into a hierarchical cluster analysis using the Ward aggregation method and the square Euclidean distance as a measure of dissimilarity. As a decision criterion on the number of clusters to be retained, a visual inspection of the 
dendogram produced was done, choosing the solution with the lowest number of clusters. The classification of the retained clusters was later refined through a non-hierarchical K-means procedure. One-way ANOVA was used to compare the variables that formed the clusters. The association between categories and clusters that were formed was performed using Pearson's Chi-square and Fisher's exact test if necessary. The Kruskal-Wallis test was performed to identify differences in the quantitative variables among the clusters. All analyzes were performed in SPSS statistics v.21 software, adopting a significance level of $\mathrm{p}<0.05$.

\section{Results}

During the study period, there were 639 hospitalizations in the pulmonology ward, of which 102 were initially diagnosed as eCOPD, according to the International Code of Diseases (ICD), while 537 received other diagnoses. Of the 102 patients, 57 patients were excluded: 19 did not have diagnostic confirmation of COPD, and 38 did not meet the inclusion criteria. Of the 537 patients initially admitted with other ICD codes, 30 ultimately had a diagnosis of exacerbation of COPD, i.e., there were 75 (12\%) admissions for COPD (Figure 1), of which 27 were readmissions - 18 patients returned once and eight more than once, and of the total number of readmissions, nine were early readmissions (less than 30 days after last hospital discharge for eCOPD) - and 48 were first-time admissions.

The sample was composed of the 48 patients admitted for the first time, who underwent anthropometric data verification and application of objective tests to assess dyspnea, symptoms (CAT), anxiety and depression, and laboratory parameters.

The duration of the first stay of each patient in the study period was $17 \pm 16.5$ (2-75) days. The outcomes of the 75 hospitalizations for eCOPD were: 28 (37\%) for hospital discharge, 27 (36\%) for discharge + readmission, and seven $(9 \%)$ deaths. Of the seven deaths, five occurred in readmissions.

Table 1 shows that half of the individuals were male; $90 \%$ were white; the mean age was $73.5 \pm 7.37$ (51-94) years; smoking amounted to $44 \pm 29(10-155)$ pack-years; 37 (77\%) were former smokers; 20 (42\%) reported exposure to wood stoves; 8 (17\%) had had bronchitis in childhood; 33 (69\%) $\mathrm{had} \geq 2$ exacerbations in the previous year; mean follow-up time with a pulmonologist was $6 \pm 5(0.5-17)$ years; the number of spirometries per patient prior to admission was $3 \pm 2$ (1-9); pre-bd $\mathrm{FEV}_{1}$ was $1.1 \pm 0.4(0.4-2.1) \mathrm{L}$ and $44 \% \pm 17 \%$ (16-79) of the predicted value; 40 (92\%) of the patients had a post-bd $\mathrm{FEV}_{1}$ of $1.1 \pm 0.4(0.5-2.2) \mathrm{L}$ and $46 \% \pm 17 \%(25-88)$ of the predicted, and 22 (46\%) were oxygen dependent.

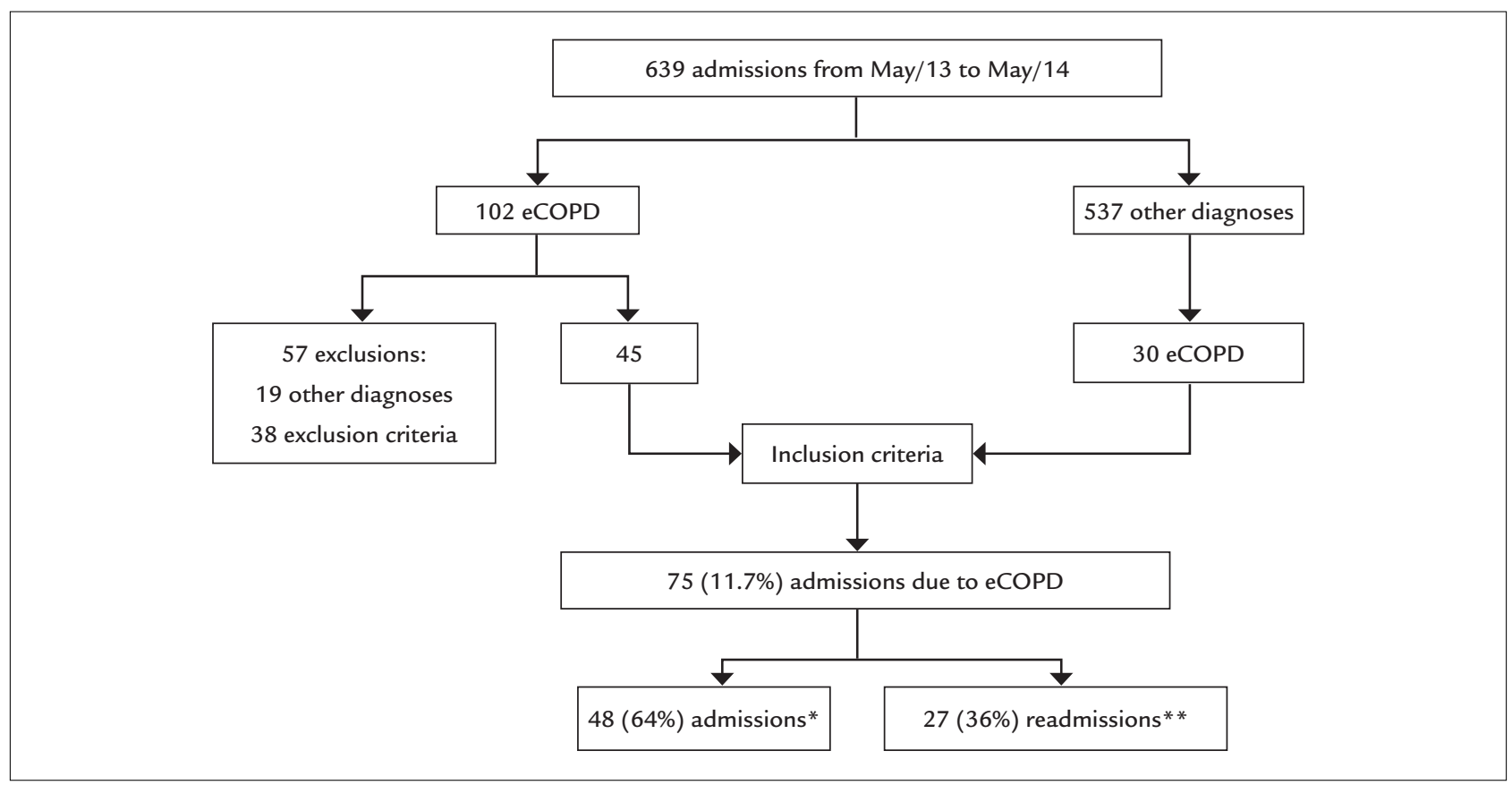

FIGURE 1 Flowchart study.

*First admission in the study period

**18 (37.5\%) patients readmitted, 8 more than once, with a total of 27 readmissions, 9 early ( $\leq 30$ days).

\# 30 (62.5\%) hospital discharges

\# 7 deaths $\left\{\begin{array}{l}5 \text { deaths ocurred in readmissions } \\ 2 \text { deathe }\end{array}\right.$

$\left\{\begin{array}{l}2 \text { deaths in the first admission } \\ \text {. }\end{array}\right.$ 
TABLE 1 Characteristics of the 48 patients.

Results as $\mathbf{n}(\%)$ or \pm SD (min-max):

\begin{tabular}{|c|c|c|}
\hline Male & 24 & $50 \%$ \\
\hline White & 43 & $90 \%$ \\
\hline Age & $73 \pm 7.4$ & (51-94 years) \\
\hline $\mathrm{BMI}$ & $26 \pm 7$ & $(15-56)$ \\
\hline Years-pack & $44 \pm 29$ & $(10-155)$ \\
\hline Former smokers & 37 & $77 \%$ \\
\hline Exposure to wood stoves & 20 & $42 \%$ \\
\hline Bronchitis in childhood & 8 & $17 \%$ \\
\hline$\geq 2$ exacerbations in the previous year & 33 & $69 \%$ \\
\hline n. of comorbidities in $48(100 \%)^{*}$ & $4.2 \pm 2.2$ & $(1-9)$ \\
\hline Divo classification in $24(50 \%)$ & $0.8 \pm 0.9$ & $(0-3)$ \\
\hline COTE index in $22(46 \%)$ & $1.9 \pm 2.6$ & $(0-8)$ \\
\hline COTE index $\geq 4$ & 10 & $21 \%$ \\
\hline Time of FUP & $6.2 \pm 4.6$ & $(0.5-17)$ \\
\hline n. of spirometries/patient & $3 \pm 2.1$ & $(1-9)$ \\
\hline $\mathrm{FEV}_{1}$, pre-bd L & $1.1 \pm 0.4$ & $(0.4-2.1)$ \\
\hline$\%$ predicted $\mathrm{FEV}_{1}$, pre & $44 \pm 17$ & $(16-79)$ \\
\hline $\mathrm{FEV}_{1} / \mathrm{FVC}$, pre & $48 \pm 10$ & $(27-69)$ \\
\hline $\mathrm{FEV}_{1}$, post-bd L** & $1.1 \pm 0.4$ & $(0.5-2.2)$ \\
\hline$\% \mathrm{FEV}_{1}$, post $^{* *}$ & $46 \pm 17$ & $(15-88)$ \\
\hline $\mathrm{FEV}_{1} / \mathrm{FVC}$, post $^{* *}$ & $47 \pm 09$ & $(23-65)$ \\
\hline Home $\mathrm{O}_{2}$ therapy & 22 & $46 \%$ \\
\hline
\end{tabular}

BMI: body mass index $\left(\mathrm{kg} / \mathrm{m}^{2}\right)$; $\mathrm{FEV}_{1}$, pre or post: forced expiratory volume in one second, performed before or following bronchodilator administration; \% predicted: percentage of the predicted value according to age and height; FVC: forced vital capacity; FUP: follow-up with a pulmonologist.

*High blood pressure,, cardiovascular diseases, DM, dyslipidemia, hypothyroidism, rheumatic diseases, liver disease, non-dialytic renal insufficiency, cancer, osteoporosis, gastrointestinal diseases. **40 patients.

The number of comorbidities found in 48 patients was 4.2 \pm 2.2 (1-9): high blood pressure, cardiovascular disease, diabetes mellitus, dyslipidemia, hypothyroidism, rheumatic diseases, liver diseases, non-dialytic kidney failure, cancer, osteoporosis and gastrointestinal diseases. According to the criteria by Divo, ${ }^{6} 24(50 \%)$ had comorbidities that increased the risk of death. Ten patients (21\%) had Cote score $\geq 4$, of whom two died.

The causes for the seven deaths were: respiratory failure in four patients who had advanced COPD and used $\mathrm{O}_{2}$ at home, and cancer in three patients (lung, breast and undetermined primary site carcinomatosis).

The results of the dyspnea, CAT and HAD scales were: high/very high impact of exacerbation in the patient's life according to CAT in $25(50 \%)$ patients, moderate impact in 15 (33\%), and low impact in five (11\%); degree of dyspnea from 0 (poor) to 100 (optimal) $\mathrm{mm}$ according to VAS at $48 \pm 29$ (4-100) $\mathrm{mm}$; and mMRC at $3 \pm 1(1-4)$.
Anxiety was present in 15 (31\%), depression in 17 (35\%) and anxiety plus depression in seven (14.5\%). Regarding laboratory tests at admission, CRP was increased in 38 (89\%) patients; there was leukocytosis (leukocytes > 10,000) in 30 (62.5\%); eosinophilia > $2 \%$ in eight (17\%); and BNP > 100 in $16(39 \%)$, ranging from $303 \pm 201$ (112-809).

Age, $\mathrm{FEV}_{1}, \mathrm{BMI}$ and CAT were variables correlated with disease severity and grouped for cluster analysis. This analysis was performed with 45 valid measures of $\mathrm{CAT}$, age, pre-bd $\mathrm{FEV}_{1}$ and $\mathrm{BMI}$, whose values, in addition to the $Z$ score, discriminated three clusters with $p<0.05$. The square Euclidean distances between patients generated a dendogram, with three clusters on visual inspection. The classification of each individual in the three clusters was refined with the "K-means" method and is shown in Figure 2.

- Cluster no. 1 had eight (16.7\%) patients, 75\% female and $25 \%$ male with age close to the mean, higher CAT and BMI results, and lower $\mathrm{FEV}_{1}$.

- Cluster no. 2 included 14 (31\%) patients, who were older and had higher CAT results, BMI within normal range and also lower $\mathrm{FEV}_{1}$.

- Cluster no. 3 had 23 (51\%) patients who were younger than the average, with a lower CAT score, BMI compatible with overweight and higher values for $\mathrm{FEV}_{1}$.

The hospitalization outcomes (discharge, readmission and death) and other characteristics of the sample, except for mMRC, did not present a statistically significant difference between the clusters. The mMRC presented a statistically significant difference among the clusters $(\mathrm{p}=0.001)$.

All patients with the exception of three had eCOPD due to infection. Antibiotics were prescribed for 45 (94\%) of the patients, of whom 34 (75.5\%) progressed well. However, $11(24.4 \%)$ patients had an unfavorable outcome and there was a need for initial antibiotic therapy replacement. Tuberculosis was diagnosed in one of the patients in the study sample.

\section{Discussion}

Admissions in the pulmonology ward of HSPE due to eCOPD accounted for $12 \%$ of the total number of admissions from May/2013 to May/2014. The rate of COPD underdiagnosis was $5 \%(30 / 537)$, while overdiagnosis occurred in 18\% (19/102). The rate of COPD underdiagnosis in São Paulo is $14 \% .{ }^{1}$ In the US, this rate reaches $50 \%$, and occurs due to several factors such as lack of knowledge about COPD or lack of suspicion for its diagnosis, which often occurs during the exacerbation. ${ }^{18,19}$ 


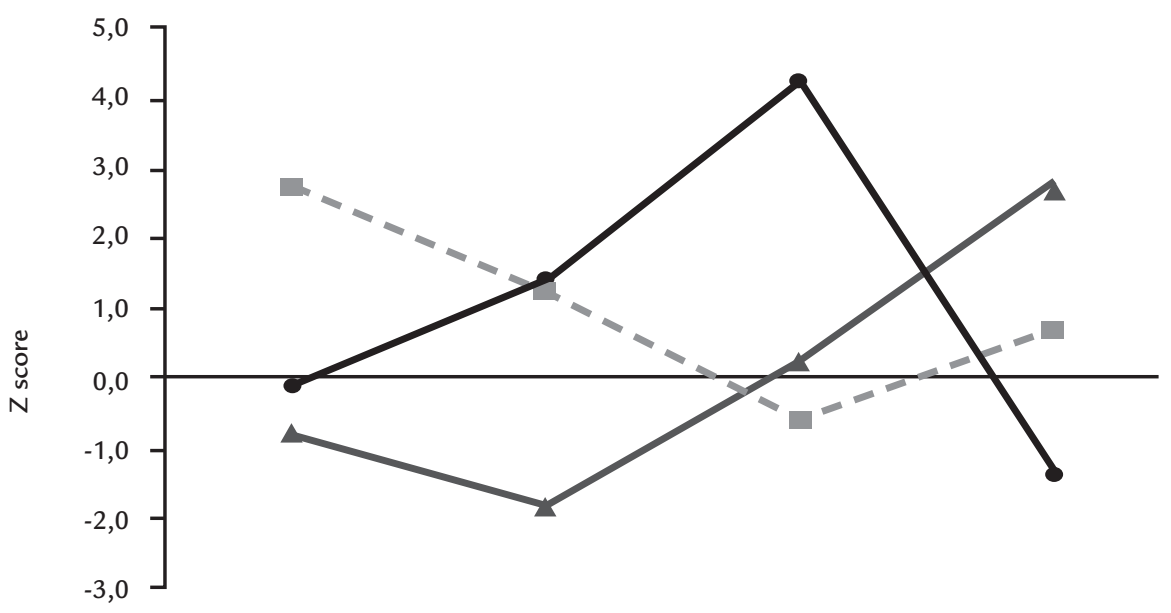

\begin{tabular}{l|l|l|l|l|} 
& Age (years) & CAT (total) & BMI $\left(\mathbf{k g} / \mathbf{m}^{2}\right)$ & FEV \\
& pre $(L)$ & \\
\hline Cluster $1(n=8)$ & $73 \pm 3$ & $26 \pm 5$ & $37 \pm 8$ & $0.94 \pm 0.28$ \\
\hline Cluster 2 $(n=14)$ & $77 \pm 7$ & $22 \pm 7$ & $23 \pm 4$ & $0.85 \pm 0.24$ \\
\hline Cluster 3 $(n=23)$ & $69 \pm 6$ & $18 \pm 6$ & $26 \pm 3$ & $1.45 \pm 0.40$ \\
\hline $\mathrm{P}(<0.05)$ & 0.003 & 0.035 & $<0.001$ & $<0.001$ \\
\hline
\end{tabular}

FIGURE 2 Standardized variables related to disease severity (age, CAT, FEV 1 and BMI) allowed grouping of patients into three clusters.

Table 1 shows that patients have a high average age and that in some the follow-up period with a pulmonologist was only 6 months, that is, the diagnosis was recent, and as a consequence, the number of spirometries performed was small. It is interesting to note that several patients (38) were not included in the study because they had never undergone spirometry (inclusion criteria), a fundamental exam for the diagnosis of COPD.$^{18} \mathrm{COPD}$ underdiagnosis results in late recognition of the disease and in later stages. ${ }^{19,20}$ Early detection of airflow limitation and smoking cessation intervention may delay the decline of lung function, reduce COPD symptoms, and improve the patient's quality of life.

In a retrospective study of COPD patients hospitalized for respiratory failure over a period of 8 years, only $31 \%$ had a diagnosis confirmed by spirometry despite having a clinical diagnosis of eCOPD,${ }^{19}$ which characterizes overdiagnosis.

Patients with a smoking load $\geq 10$ packs/year were included in this study. Smoking is the most frequent cause of COPD, although there are other risk factors such as exposure to occupational dust, air pollution and biomass burning. ${ }^{20}$ We observed that $42 \%$ of our patients reported exposure to wood stoves.
Still in relation to the characteristics of the sample, $17 \%$ of the patients had a history of bronchitis in childhood. It is known that the prevalence of asthmatics who smoke is similar to that of the general population, and that many COPD patients may present a history of asthma prior to COPD. COPD is often confused with asthma. ${ }^{21,22}$ The coexistence of these conditions is called asma-COPD overlap syndrome. ${ }^{23}$ With increasing age, there is an increase in the proportion of patients with this syndrome. Some studies found that $55 \%$ of COPD patients over 50 years of age had asthma, whereas in other studies the prevalence of asthma-COPD overlap syndrome ranged from 13 to $19 \% .{ }^{23}$

Patients hospitalized with eCOPD had $4.2 \pm 2.2$ comorbidities, which is consistent with reports in the medical literature that these are more frequent in patients with COPD than in the general population. ${ }^{24}$ Some comorbidities present in patients with COPD affect the prognosis, as described by Divo and Cote. ${ }^{6}$ In our study, the Cote score was higher than 4 for ten patients $(21 \%)$, which means an increased risk of death. There is evidence that the specific management of COPD reduces the number of exacerbations leading to clinical stability for comorbidities with reduced mortality. The same happens with the treatment of comorbidities, which affects the stability of COPD. ${ }^{24,25}$ 
Management of COPD aims to control symptoms and comorbidities, and prevent exacerbations. ${ }^{3}$ Hospitalization due to eCOPD does not necessarily occur in patients with more advanced disease ${ }^{26}$ and, in our study, we found that the patients had different grades of severity, despite the fact that $\mathrm{FEV}_{1}$ pre-bd was $44 \% \pm 17 \%$, and 22 (45\%) patients used oxygen at home.

Mortality in eCOPD is high and we observed in our study frequent readmissions that correlated with the outcome of death, as described by Hurst,,$^{27}$ Soriano, ${ }^{28}$ and Teixeira, ${ }^{29}$ the latter in Brazil. Teixeira says that $87.8 \%$ of the patients hospitalized with COPD had two or more comorbidities, and hospital mortality due to eCOPD was $37.7 \%$.

The length of hospital stay was $18 \pm 17$ days. We observed the heterogeneity of clinical manifestations in COPD patients through CAT variability and dyspnea as measured by mMRC and VAS. ${ }^{30}$ There is a correlation between high CAT score and higher frequency of exacerbations, reflecting both severity and duration. CAT may assist in assessing the severity of the exacerbation. ${ }^{12,31}$

The prevalence of depression found in the sample was $35 \%$. Coexistence of anxiety and/or depression with COPD increases the number of exacerbations and hospitalizations. ${ }^{8,32}$

Biomarkers are useful to monitor patients admitted with eCOPD. The presence of eosinophilia > $2 \%$ indicates a better response to steroid therapy, ${ }^{16}$ and it was found in $20 \%$ of the patients. CRP and BNP are useful biomarkers for monitoring, respectively, infectious exacerbations and cardiopathies. ${ }^{17,26,33}$

The seven deaths reported in our study were due to respiratory failure (four patients) and cancer (three patients). Respiratory failure correlates with more severe COPD, whereas lung cancer affects $9 \%$ of COPD patients, regardless of staging. ${ }^{28}$

The standardized analysis of age, CAT, $\mathrm{FEV}_{1}$ and BMI allowed grouping of patients into three clusters (Figure 2), with different degrees of severity and no correlation with the outcomes of hospitalization. In the first group there were more women with lower $\mathrm{FEV}_{1}$, higher BMI, and CAT displaying high scores. In the second group, there were older patients with high CAT; and in the third group, younger patients, with higher $\mathrm{FEV}_{1}$ and lower CAT scores, which indicates less severe COPD in this group with a greater number of patients. ${ }^{34}$

Readmissions due to eCOPD are a marker of poor prognosis. The number of readmissions was high in our study, which points to the need to adopt protocols for hospital discharge and appointment scheduling soon after discharge, with referral to a pulmonary rehabilitation program. ${ }^{35}$
The small number of patients included in the sample was a limitation in our study, and was due to a high rate of readmissions and failure to meet the inclusion criteria.

COPD exacerbation is an event that often requires hospitalization and progresses with a high mortality rate. Many times, COPD is under- or overdiagnosed, and one reason is underutilization of spirometry. Thorough assessment of these patients on admission, using laboratory tests, comorbidities assessment, and objective instruments to quantify dyspnea and symptoms (mMRC, VAS and CAT) is essential to reduce hospital stay, prevent readmission and decrease mortality. ${ }^{36,37}$

Patients admitted due to eCOPD are a heterogeneous group that can be grouped into three clusters as described, although we did not find an association between these clusters and the outcomes of hospitalization. Studies with a larger sample of patients are needed to confirm the findings reported here and to relate them to the outcomes of hospitalizations due to eCOPD.

\section{Resumo}

Hospitalização por exacerbação da DPOC: desfechos da "vida real"

Introdução: As hospitalizações por exacerbação da doença pulmonar obstrutiva crônica (eDPOC) podem indicar um pior prognóstico. É importante conhecer o perfil dos pacientes internados e os desfechos das internações para personalizar e otimizar seu tratamento.

Método: Avaliação dos pacientes hospitalizados por eDPOC, $c 0 m \geq 10$ anos/maços e $\geq 1$ espirometria prévia com obstrução ao fluxo aéreo no período de um ano em um serviço de pneumologia de um hospital geral. Foram utilizados: teste de avaliação da DPOC (CAT); mMRC e Escala Analógica Visual (EAV) para aferição da dispneia; escala hospitalar de ansiedade e depressão (HAD); comorbidades pelos critérios de Divo e índice de Cote; espirometria; e exames laboratoriais, eosinófilos no sangue, proteína $C$ reativa (PCR), brain natriuretic peptide (BNP). Observamos evolução dos pacientes, duração da internação e desfechos da hospitalização.

Resultados: Ocorreram 75 (12\%) internações por eDPOC, sendo 27 reinternações, nove das quais com menos de 30 dias após a alta. Os principais desfechos foram: duração da internação de $17 \pm 16,5$ (2-75) dias; 30 (62,5\%) altas hospitalares; 18 (37,5\%) altas/reinternações, oito pacientes reinternaram mais de uma vez; e sete $(14,5 \%)$ óbitos, cinco durante as reinternações. Analisamos 48 pacientes em sua primeira internação. A amostra era um grupo heterogêneo 
que ordenamos em três clusters de acordo com idade, $\mathrm{VEF}_{1}$, índice de massa corporal (IMC) e CAT. Os clusters não se correlacionaram com os principais desfechos.

Conclusão: A eDPOC é causa frequente de internações. Foram frequentes as reinternações e estas se correlacionaram com o desfecho óbito. Os pacientes internados por eDPOC formaram um grupo heterogêneo, que pôde ser agrupado em três clusters com diferentes graus de gravidade e sem correlação com os desfechos das hospitalizações.

Palavras-chave: hospitalização por exacerbação da DPOC, exacerbação da DPOC, teste de avaliação da DPOC, Escala Analógica Visual, morte por DPOC.

\section{References}

1. Projeto Latino-Americano de Investigação e Obstrução Pulmonar. PLATINO. Brasil. Available from: http://www.platino-alat.org.

2. Moreira GL, Manzano BM, Gazzotti MR, Nascimento OA, Perez-Padill R, Menezes AMB et al. PLATINO, a nine-year follow-up study of COPD in the city of São Paulo, Brazil: the problem of underdiagnosi. J Bras Pneumol. 2014; 40(1):30-7.

3. Global Initiative for Chronic Obstructive Lung Disease (Updated 2015). Available from: http://goldcopd.it/wp-content/uploads/materiali/2015/ Gold_Pocket_DEF_2015.pdf

4. Toyoshima MTK, Ito GM, Gouveia N. Morbidades por doenças respiratórias em pacientes hospitalizados em São Paulo/SP. Rev Assoc Med Bras. 2005; 51(4):209-13.

5. Brasil. Ministério da Saúde. Departamento de Informática do SUS. Brasília (DF): DATASUS; 2010. Available from: http://www2.datasus.gov.br/DATASUS/ index.php. Cited in "Protocolo Clínico e Diretrizes Terapêuticas (PCDT) Doença Pulmonar Obstrutiva Crônica”, regulamentado pela PORTARIA N ${ }^{\circ}$ 609, 6 de junho de 2013, do Ministério da Saúde Secretaria de Atenção à Saúde. CONITEC Comissão Nacional de Incorporação de Tecnologias ao SUS.

6. Divo M, Cote C, Torres JP, Casanova C, Marin JM, Pinto-Plata V, et al.; BODE Collaborative Group. Comorbidities and risk of mortality in patients with chronic obstructive pulmonary disease. Am J Respir Crit Care Med. 2012; 186(2):155-61.

7. Nussbaumer-Ochsner Y, Rabe KF. Systemic manifestations of COPD. Chest. 2011; 139(1):165-73.

8. Maurer J, Rebbapragada V, Borson S, Goldstein R, Kunik ME, Yohannes AM, et al. Anxiety and depression in COPD: current understanding, unanswered questions, and research needs. Chest. 2008; 134(4 Suppl):43s-56s.

9. Botega NJ, Bio MR, Zomignani MA, Garcia Jr C, Pereira WAB. Transtornos do humor em enfermaria de clínica médica e validação de escala de medida (HAD) de ansiedade e depressão. Rev Saúde Pública. 1999; 29(5):355-63.

10. Camargo LACR, Pereira CAC. Dispneia em DPOC: além da escala modified Medical Research Council. J Bras Pneumol. 2010; 36(5):571-8.

11. Jones PW, Harding G, Berry P, Wiklund I, Chen WH, Kline Leidy NK. Development and first validation of the COPD Assessment Test. Eur Respir J. 2009; 34(4):648-54.

12. Mackay AJ, Donaldson GC, Patel ARC, Jones PW, Hurst JR, Wedzicha JA. Usefulness of the Chronic Obstructive Pulmonary Disease Assessment Test to evaluate severity of COPD exacerbations. Am J Respir Crit Care Med. 2012; 185(11):1218-24.

13. Silva GPFS, Morano MTAP, Viana CMS, Magalhães CBA, Pereira EDB. Portuguese-language version of the COPD Assessment Test: validation for use in Brazil. J Bras Pneumol. 2013; 39(4):402-8.

14. Quon BS, Gan WQ, Sin DD. Contemporary management of acute exacerbations of COPD: a systematic review and metaanalysis. Chest. 2008; 133(3):756-66.

15. Marchiori RC, Susin CF, Dal Lago L, Felice CD, Brandão da Silva D, Severo MD. Diagnóstico e tratamento da DPOC exacerbada na emergência. AMRIGS (Porto Alegre). 2010; 54(2):214-23.
16. Bafadhel M, McKenna S, Terry S, Mistry V, Pancholi M, Veng P, et al. Blood eosinophils to direct corticosteroid treatment of exacerbations of chronic obstructive pulmonary disease: a randomized placebo-controlled trial. Am J Respir Crit Care Med. 2012; 186(1):48-55

17. Chen YW, Leung JM, Sin DD. A systematic review of diagnostic biomarkers of COPD exacerbation. PLoS One. 2016; 11(7):e0158843.

18. Price D, Crockett A, Arne M, Garbe B, Jones R, Kaplan A, et al. Spirometry in primary care case-identification, diagnosis and management of COPD. Prim Care Respir J. 2009; 18(3):216-23.

19. Fromer L. Diagnosing and treating COPD: understanding the challenges and finding solutions. Int J Gen Med. 2011; 4:729-39.

20. Tan WC, Sin DD, Bourbeau J, Hernandez P, Chapman KR, Cowie R, et al.; CanCOLD Collaborative Research Group. Characteristics of COPD in neversmokers and ever-smokers in the general population: results from the CanCOLD study. Thorax. 2015; 70(9):822-9.

21. Fu JJ, Gibson PG, Simpson JL, McDonald VM. Longitudinal changes in clinical outcomes in older patients with asthma, COPD and asthma-COPD Overlap Syndrome. Respiration. 2014; 87(1):63-74.

22. Diagnosis of Diseases of Chronic Airflow Limitation: Asthma, COPD and Asthma-COPD Overlap Syndrome (ACOS). A joint project of GINA and GOLD 2014. This chapter is excerpted from the Global Strategy for Asthma Management and Prevention, 2014. Available from: http://www. ginasthma.org.

23. Turner AM, Tamasi L, Schleich F, Hoxha M, Horvath I, Louis R, et al. Clinically relevant subgroups in COPD and asthma. Eur Respir Rev. 2015; 24(136):283-98.

24. Echave-Sustaeta JM, Comeche Casanova L, Cosio BG, Soler-Cataluña JJ, Garcia-Lujan R, Ribera X. Comorbidity in chronic obstructive pulmonary disease. Related to disease severity? Int J Chron Obstruct Pulomon Dis. 2014; 9:1307-14.

25. Jeong $\mathrm{SH}$, Lee H, Carriere KC, Shin SH, Moon SM, Jeong BH, et al. Comorbidity as a contributor to frequent severe acute exacerbation in COPD patients. Int J Chron Obstruct Pulmon Dis. 2016; 11:1857-65.

26. Miravitlles M, Moragas A, Hernández S, Bayona C, Llor C. Is it possible to identify exacerbations of mild to moderate COPD that do not require antibiotic treatment? Chest. 2013; 144(5):1571-7.

27. Hurst JR, Vestbo J, Anzueto A, Locantore N, Müllerova H, Tal-Singer R, et al.; Evaluation of COPD Longitudinally to Identify Predictive Surrogate Endpoints (ECLIPSE) Investigators. Susceptibility to exarcerbation in chronic obstructive pulmonary disease. N Engl J Med. 2010; 363(12):1128-38

28. Ortiz JBS, Almagro P, Sauleda Roig J. Causas de mortalidad en la EPOC. Arch Bronconeumol. 2009; 45(Supl 4):8-13.

29. Teixeira C, Cabral CR, Hass JS, Oliveira RP, Vargas MAO, Freitas APR, et al Exacerbação aguda da DPOC: mortalidade e estado funcional dois anos após a alta da UTI. J Bras Pneumol. 2011;37(3):334-40.

30. Csikesz NG, Gartman EJ. New developments in the assessment of COPD: early diagnosis is key. Int J Chron Obstruct Pulmon Dis. 2014; 9:277-86.

31. Chetta A, Olivieri D. The COPD Assessment Test in the evaluation of chronic obstructive pulmonary disease exacerbations. Expert Rev Resp Med. 2012; 6(4):373-5.

32. Pooler A, Beech R. Examining the relationship between anxiety and depression and exacerbations of COPD which result in hospital admission: a systematic review. Int J Chron Obstruct Pulmon Dis. 2014; 9:315-30.

33. Patel AR, Hurst JR, Wedzicha JA. The potencial value of biomarkers in diagnosis and staging of COPD and exacerbations. Semin Respir Crit Care Med. 2010; 31(3):267-75

34. Burgel PR, Paillasseur JL, Caillaud D, Tillie-Leblond I, Chanez P, Escamilla $\mathrm{R}$, et al. Longitudinal validation of clinical COPD phenotypes identified by cluster analysis. Eur Respir J. 2010; 36:531-9.

35. Hurst JR, Wedzicha JA. Management and prevention of chronic obstructive pulmonary disease exacerbations: a state of the art review. BMC Med. $2009 ; 7: 40$

36. Müllerova H, Maselli DJ, Locantore N, Vestbo J, Hurst JR, Wedzicha JA, et al. Hospitalized exacerbations of COPD: risk factors and outcomes in the ECLIPSE cohort. Chest. 2015; 147(4):999-1007.

37. Santibáñez M, Garrastazu R, Ruiz-Nuñez M, Helguera JM, Arenal S, Bonnardeux $\mathrm{C}$, et al. Predictors of hospitalized exacerbations and mortality in chronic obstructive disease. PLoS One. 2016; 11(6):e0158727. 